\title{
GENETIC RESISTANCE TO THE CEREAL CYST NEMATODE (HETERODERA AVENAE)
}

\author{
J. COTTEN* and J. D. HAYES \\ Welsh Plant Breeding Station, Aberystwyth
}

Received 11.xii;68

\section{INTRODUGTION}

The cereal cyst nematode (Heterodera avenae Woll.) is a soil-borne parasite of barley, oat and wheat, and is characterised by the development of the adult females into lemon-shaped cysts which are clearly visible on the roots of the host plant. Each cyst contains several hundred larvae and provides the souree of infection for the following year.

In certain genotypes of barley, the female fails to reach maturity and consequently no cysts are found on the roots; this resistance is being introduced into modern barley cultivars. Up to the present, breeders have used two main sources of resistance. The existence of nematode races capable of attacking both sources, and the availability of other types of resistance, necessitate a knowledge of the genetic inter-relationships of various factors for resistance to different pathotypes before the next stage in the resistance breeding programmecan be planned. Populations of the cereal cyst nematode vary in pathogenicity, i.e. in their ability to form cysts on the same host (Andersen, 1961 ; Cotten, 1963, 1967; Kort et al., 1964). The two races, designated 1 and 2 in Denmark and Britain, and A and $C$ in the Netherlands, make up the bulk of the British populations. In this investigation the inheritance of resistance of six unrelated barley genotypes was studied using two populations of the cereal cyst nematode known to differ in their pathogenicity.

\section{Materials AND Methods}

A description of the resistant parents employed, the susceptible control $\mathrm{Cb} 545$ (Rika) and their reaction to races 1 and 2 are presented in table 1 .

The parents, $F_{1}$ hybrids, and $F_{2}$ segregates were tested for nematode reaction against two nematode populations designated 1 and 2 which were similar in pathogenicity reaction to races 1 and 2 . Individual seedlings were planted in $3 \frac{1}{2}$ in. diameter $(8 \mathrm{~cm}$.) pots of infested soil in March. The pots were arranged in a randomised block layout, with the populations treated as two separate experiments. At ear emergence (10-12 weeks after planting), the number of white cysts on the root system of each plant was determined by the method described by Cotten (1967).

The classification of $\mathrm{F}_{2}$ segregates was based on the reaction of the homozygous resistant and susceptible parents and heterozygous $F_{1}$ plants grown in a randomised block layout, using the same source of soil inoculum for all blocks in each experiment. After a square root transformation, the mean and standard deviation were computed for each parent and $F_{1}$ hybrid population, and members of the $\mathrm{F}_{2}$ populations were classified according to their highest level of probability of being included in a particular parental group. In no case did an $\mathrm{F}_{2}$ segregate fall outside the 95 per cent. level of probability of belonging to a particular parental class.

\footnotetext{
* Present address: Plant Pathology Laboratory, Harpenden, Herts.
} 
TABLE 1

Designation and origin of seven barley genotypes and their reaction to races 1 and 2

\begin{tabular}{|c|c|c|c|c|}
\hline \multirow{2}{*}{$\begin{array}{l}\text { W.P.B.S. } \\
\text { accession } \\
\text { number }\end{array}$} & \multirow{2}{*}{$\begin{array}{l}\text { Varietal name } \\
\text { or other } \\
\text { designation }\end{array}$} & \multirow[b]{2}{*}{ Source of seed } & \multicolumn{2}{|c|}{$\begin{array}{c}\text { Cereal cyst } \\
\text { nematode reaction }\end{array}$} \\
\hline & & & Race 1 & Race 2 \\
\hline $\mathrm{Cb} 545$ & Rika & W.P.B.S. stock & + & + \\
\hline $\begin{array}{l}\text { Cb } 917 \\
\text { Cb } 918 \\
\text { Cb } 824 \\
\text { Cb } 1018\end{array}$ & $\begin{array}{l}\text { Fero } \\
\text { Drost } \\
\text { No. } 191 \\
\text { No. } 14\end{array}$ & $\begin{array}{l}\text { Professor Sigurd } \\
\text { Andersen, } \\
\text { Copenhagen, } \\
\text { Denmark }\end{array}$ & $\begin{array}{l}- \\
- \\
-\end{array}$ & $\begin{array}{l}+ \\
+ \\
-\end{array}$ \\
\hline $\begin{array}{l}\mathrm{Cb} 1022 \\
\mathrm{Cb} 1023\end{array}$ & $\begin{array}{l}\text { C.I. } 8334 \\
\text { C.I. } 3902\end{array}$ & $\begin{array}{l}\text { Dr Van Essen } \\
\text { Wageningen, } \\
\text { Netherlands }\end{array}$ & $\overline{-}$ & $\overline{-}$ \\
\hline
\end{tabular}

TABLE 2

The range of number of cysts produced on parents, $F_{1}$, and $F_{2}$ plants of a 5 parent diallel when tested against two populations of the cereal cyst nematode

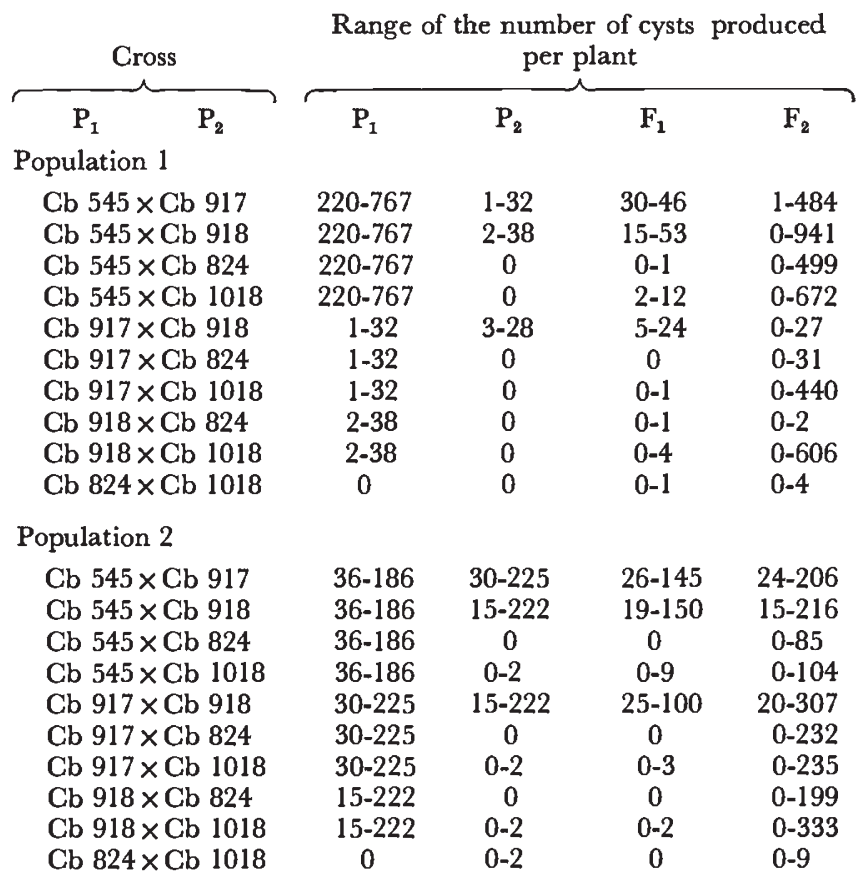

\section{Results}

(i) Interrelationships of genes for resistance

The range of cyst numbers produced on the parents, $F_{1}$, and $F_{2}$ segregates when tested against population 1 and 2, are given in table 2. Analysis of variance followed by Duncan's Multiple Range Test applied to all the parent and $\mathrm{F}_{1}$ data (but excluding $\mathrm{Cb} 824$ and $\mathrm{Cb} 1018$ and their hybrids) 
showed that, when tested against population $1, \mathrm{Cb} 917$ and $\mathrm{Cb} 918$ and their hybrids, although not fully resistant like $\mathrm{Cb} 824$ and $\mathrm{Cb} 1018$, had significantly fewer cysts than $\mathrm{Cb} 545$. Tested against population $2, \mathrm{Cb} 545, \mathrm{Cb}$ 917 and $\mathrm{Cb} 918$ produced a similar number of cysts, and all three could be considered as fully susceptible. The number of cysts found on $\mathrm{Cb} 545$, when tested against population 1, ranged from 220 to 767 and, against population 2 , from 36 to 186 , the actual number of cysts produced depending partly on the level of inoculum in the soil.

TABLE 3

Observed and expected $F_{2}$ frequencies with levels of probabilities of data fitting hypothesis outlined in text

Population 1

\begin{tabular}{|c|c|c|c|c|}
\hline Parents & $\mathrm{Cb} 917$ & $\mathrm{Cb} 918$ & $\mathrm{Cb} 824$ & Cb 1018 \\
\hline Cb 545 & $\begin{array}{r}\mathbf{R} S \\
O=12: 8 \\
P_{3: 1}>0 \cdot 10\end{array}$ & $\begin{array}{r}R S \\
O=33: 7 \\
P_{3: 1}>0 \cdot 20\end{array}$ & $\begin{array}{l}\mathrm{R} S \\
\mathrm{O}=21: 4 \\
\mathrm{P}_{3: 1}>0 \cdot 20\end{array}$ & $\begin{array}{r}R S \\
O=12: 8 \\
P_{3: 1}>0 \cdot 10\end{array}$ \\
\hline $\mathrm{Cb} 917$ & - & $\begin{array}{c}\mathrm{O}=20: 0 \\
\text { No test }\end{array}$ & $\begin{array}{l}\mathrm{O}=20: 0 \\
\text { No test }\end{array}$ & $\begin{array}{l}O=17: 3 \\
P_{15: 1}>0 \cdot 10\end{array}$ \\
\hline Cb 918 & - & - & $\begin{array}{c}\mathrm{O}=44: 0 \\
\text { No test }\end{array}$ & $\begin{array}{l}O=18: 2 \\
P_{15: 1}>0 \cdot 30\end{array}$ \\
\hline $\mathrm{Cb} 824$ & 一 & - & - & $\begin{array}{c}\mathrm{O}=20: 0 \\
\text { No test }\end{array}$ \\
\hline \multicolumn{5}{|c|}{ Population 2} \\
\hline Parents & $\mathrm{Cb} 917$ & $\mathrm{Cb} 918$ & $\mathrm{Cb} 824$ & $\mathrm{Cb} 1018$ \\
\hline Cb 545 & $\mathrm{O}=\begin{array}{r}\mathrm{R} \\
\mathrm{S}: 19\end{array}$ & $\mathrm{O}=\begin{array}{r}\mathbf{R} \quad \mathbf{S} \\
0: 39\end{array}$ & $\begin{array}{r}R_{S} S \\
\mathrm{O}=18: 7 \\
\mathrm{P}_{3: 1}>0.70\end{array}$ & $\begin{array}{l}\mathrm{R} S \\
\mathrm{O}=14: 6 \\
\mathrm{P}_{3: 1}>0 \cdot 50\end{array}$ \\
\hline $\mathrm{Cb} 917$ & - & $\mathrm{O}=0: 20$ & $\begin{array}{l}O=8: 10 \\
P_{3: 1}<0 \cdot 01\end{array}$ & $\begin{array}{l}O=14: 6 \\
P_{3: 1}>0.50\end{array}$ \\
\hline $\mathrm{Cb} 918$ & - & - & $\begin{array}{l}O=32: 11 \\
P_{3: 1}>0.90\end{array}$ & $\begin{array}{l}O=13: 7 \\
P_{3: 1}>0 \cdot 30\end{array}$ \\
\hline $\mathrm{Cb} 824$ & - & - & - & $\begin{array}{c}O=20: 0 \\
\text { No test }\end{array}$ \\
\hline
\end{tabular}

$F_{1}$ hybrid $\mathrm{Cb} 918 \times \mathrm{Cb} 824$

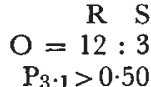

When tested against population 1 the resistance of $\mathrm{Cb} 824$ was epistatic to the partial resistance of $\mathrm{Cb} 917$ and $\mathrm{Cb} 918$, and dominant to the susceptibility of $\mathrm{Cb} 545$. The partial resistance of $\mathrm{Cb} 917$ and $\mathrm{Cb} 918$ to population 1 was dominant to the fully susceptible reaction of $\mathrm{Cb} 545 . \quad \mathrm{Cb} 824$ and $\mathrm{Cb} 1018$ gave similar results against both populations 1 and 2, although the resistance of $\mathrm{Cb} 1018$ was never as complete as that of $\mathrm{Cb} 824$, and similarly the $\mathrm{F}_{1}$ hybrids involving $\mathrm{Cb} 1018$ developed more cysts than those involving $\mathrm{Cb} 824$.

The $\mathrm{F}_{2}$ segregants were classified into resistant and susceptible types according to the reaction of the more resistant parent and $F_{1}$ hybrids in each cross against each population. The maximum number of cysts produced on either the homozygous resistant parent or $F_{1}$ hybrids was the approximate demarcation line between resistance and susceptibility. Thus the resistant group contained both homozygous resistant and heterozygous plants. The observed frequencies of resistant and susceptible plants classified on this basis are given in table 3 ; in addition, the expected ratios and results of $\chi^{2}$ tests 
are given, assuming that resistance to a particular pathotype is controlled by a single gene and is dominant to partial resistance and susceptibility, and that the partial resistance of $\mathrm{Cb} 917$ and $\mathrm{Cb} 918$ to population $\mathrm{l}$ is also controlled by a single dominant gene, independent of the gene for resistance in $\mathrm{Cb} 824$ and $\mathrm{Cb}$ 1018. It is evident from the segregation of the $\mathrm{F}_{2}$ progenies of $\mathrm{Cb} 917 \times \mathrm{Cb} 1018$, and $\mathrm{Cb} 918 \times \mathrm{Cb} 1018$, when tested against population 1 , that the gene for resistance in $\mathrm{Cb} 1018$ is at a different locus from that of $\mathrm{Cb} 917$ and $\mathrm{Cb} 918$; there is no evidence to suggest that the resistance genes of $\mathrm{Cb} 917$ and $\mathrm{Cb} 918$ are at different loci, although the size of the $\mathrm{F}_{2}$ populations tested is too small to preclude the possibility of close linkage.

Although no susceptible plants were recovered from the cross of $\mathrm{Cb} 917$ and $\mathrm{Cb} 918$ with $\mathrm{Cb} 824$ when tested against population $\mathrm{l}$, the results of crossing the $\mathrm{F}_{1}$ hybrid $(\mathrm{Cb} 918 \times \mathrm{Cb} 824)$ to the susceptible $\mathrm{Cb} 545$ indicate that the genes for resistance in $\mathrm{Cb} 918$ and $\mathrm{Cb} 824$ are not at the same locus.

TABLE 4

Segregation in the 9th-11th back-cross generations of the cross Cb $824 \times$ susceptible recurrent parent when tested against race 1 and 2 alternately

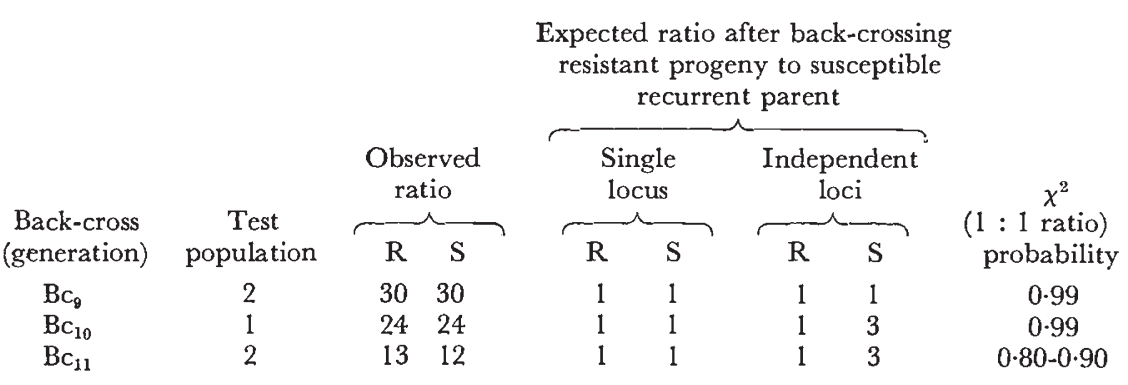

When the $F_{2}$ populations were tested against population 2 , the results indicated that a single dominant gene for resistance is operating in $\mathrm{Cb} 824$ and $\mathrm{Cb} 1018$, although the results from the cross $\mathrm{Cb} 917 \times \mathrm{Cb} 824$ do not conform with this hypothesis $(\mathrm{P}<0 \cdot 01)$. There is no evidence in these data of any segregation in the crosses $\mathrm{Cb} 824 \times \mathrm{Cb} 1018$ (table 2).

Data derived from a breeding programme designed to develop a cereal cyst nematode resistant variety show that the resistance of $\mathrm{Cb} 824$ to populations 1 and 2 is due to the same gene. $F_{1}$ hybrids from $\mathrm{Cb} 824$ crossed with a susceptible parent were back-crossed for eleven generations to a recurrent parent susceptible to both populations. Resistant back-cross hybrids were retained for further back-crossing on the basis of their reaction to mixed eelworm populations. However, back-cross hybrids were tested for the last three generations against population 1 and 2 in alternate generations (table 4).

The genetic relationship of the resistance of $\mathrm{Cb} 824$ and $\mathrm{Cb} 1018$ was clarified in a further series of crosses in which two additional resistant parents were included (table 5). In this experiment the parents, $F_{1}$ and $F_{2}$ progenies were tested against population 2 . In the $\mathrm{F}_{2}$ progeny of the cross $\mathrm{Cb} 824 \times \mathrm{Cb} \mathrm{1018,} \mathrm{two} \mathrm{plants} \mathrm{were} \mathrm{recovered} \mathrm{which} \mathrm{could} \mathrm{be} \mathrm{classed} \mathrm{as}$ susceptible, indicating that the resistance genes were located at different loci. In the $\mathrm{F}_{2}$ progenies of the other five crosses the cyst production on all the plants fell either within, or lay very close to, the range of reaction of the parents and $F_{1}$ hybrids. 
TABLE 5

Cyst production on parents, $F_{1}$ hybrids, and $F_{2}$ progeny from intercrosses of four cereal cyst nematode resistant genotypes. Tested against population 2. (Cb 545 Rika $=$ susceptible control with 3-82 cysts(plant)

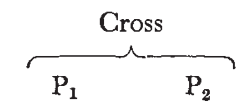

$\mathrm{Cb} 824 \times \mathrm{Cb} 1018$

$\mathrm{Cb} 824 \times \mathrm{Cb} 1022$

$\mathrm{Cb} 824 \times \mathrm{Cb} 1023$

$\mathrm{Cb} 1018 \times \mathrm{Cb} 1022$

$\mathrm{Cb} 1018 \times \mathrm{Cb} 1023$

Cb $1022 \times \mathrm{Cb} 1023$

\begin{tabular}{cccc}
\multicolumn{4}{c}{$\begin{array}{c}\text { Range of the number of cysts } \\
\text { produced/plant }\end{array}$} \\
\cline { 2 - 4 } $\mathrm{P}_{1}$ & $\mathrm{P}_{2}$ & $\mathrm{~F}_{1}$ & $\mathrm{~F}_{2}$ \\
0 & $0-2$ & $0-2$ & $0-22$ \\
0 & $0-1$ & 0 & $0-1$ \\
0 & $0-1$ & 0 & $0-1$ \\
$0-2$ & $0-1$ & 0 & $0-4$ \\
$0-2$ & $0-1$ & 0 & $0-2$ \\
$0-1$ & $0-1$ & 0 & $0-1$
\end{tabular}

$\begin{array}{cc}\begin{array}{c}\text { Observed } \\ \text { ratio }\end{array} \\ \mathrm{R}: \mathrm{S} & \mathrm{P}_{15: 1}^{\chi^{2}} \text { segregation } \\ 58: 2 & >0 \cdot 30 \\ 60: 0 & - \\ 60: 0 & - \\ 59: 0 & - \\ 60: 0 & - \\ 60: 0 & -\end{array}$

(ii) Linkage relationships of the resistance factor in $C b 824$

The locus of the major gene for resistance in $\mathrm{Cb} 824$ which is effective against pathotypes 1 and 2 has been designated $\mathrm{Ha}$. Hybrids were obtained between the two-row genotype $\mathrm{Cb} 825$, having resistance from $\mathrm{Cb} 824$, and seven genotypes which are susceptible to the cereal cyst nematode and homozygous for reciprocal translocations involving each of the seven chromosomes. The seven translocation stock parents and the techniques involved were the same as those used by Hayes and Rana (1966).

In the segregation of the $\mathrm{F}_{2}$ progenies there was no positive linkage of $\mathrm{Ha}$ with any of the break points in the seven translocation stocks. However, five of the susceptible translocation stocks used as parents were six-row (ha ha $v v$ ). In the $\mathrm{F}_{2}$ progeny of the five crosses, which included these six-row parents, an excess of six-row susceptible and two-row resistant phenotypes was recovered (table 6).

\section{TABLE 6}

The phenotypes of $F_{2}$ progenies from five families segregating for head type $(\mathrm{Vv})$, and reaction to the cereal cyst nematode (Ha ha)

Cereal cyst-nematode reaction

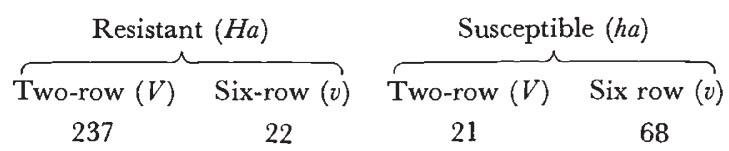

Total for five families

$237 \quad 22$

Partitioning of the chi square values (table $7 a$ ) clearly indicated that linkage between the two loci was responsible for the disturbed $F_{2}$ ratio. The heterogeneity test (table $7 b$ ) indicated that the data from the five families are homogeneous for each of the three components.

The recombination value between $H a$ and $V$ was estimated to be $13 \cdot 2 \pm 1 \cdot 96$. Since the $V v$ locus is known to be located on chromosome 2, these results demonstrate that the gene $(\mathrm{Ha})$ responsible for nematode resistance of $\mathrm{Cb} 824$ (No. 191) is also located on chromosome 2. The position of the $\mathrm{Ha}$ ha locus has been confirmed using another chromosome 2 genetic marker, the character " liguleless" $(l i)$. The $\mathrm{F}_{2}$ progeny of the cross between $\mathrm{Cb} 1113$, a six-row susceptible parent without ligules $(v, h a, l i)$ and $\mathrm{Cb} 825$, a two-row resistant parent with ligules $(\mathrm{V}, \mathrm{Ha}, \mathrm{Li})$, in addition to confirming the linkage between $V v$ and $\mathrm{Ha} h a$, also gave evidence of linkage between $\mathrm{Li} l i$ and $\mathrm{Ha} \mathrm{ha}$ (table 8). 
TABLE $7(a)$

Chi square values for segregation of cereal cyst nematode reaction $(\mathrm{Ha} \mathrm{ha})$, head type $(\mathrm{Vv})$, and linkage

$\begin{array}{lcrc}\quad \text { Character } & \text { d.f. } & \chi^{2} \text { value } & \text { Probability } \\ \text { Segregation of } H a h a & 1 & 0.14 & >0.70 \\ \text { Segregation } V v & 1 & 0.25 & >0.50 \\ \text { Linkage } & 1 & 165.59 & <0.001 \\ \text { Total } & 3 & 165.98 & <0.001\end{array}$

TABLE $7(b)$

Heterogeneity chi square test of data from five families

\begin{tabular}{lrrrr} 
& \multicolumn{3}{c}{$\chi^{2}$ values } & \\
\cline { 2 - 4 } & $\overbrace{H a}$ & $V$ & Linkage & d.f. \\
Total & 3.04 & 1.41 & 172.56 & 5 \\
Deviation & 0.14 & 0.25 & 165.59 & 1 \\
Heterogeneity & 2.90 & 1.16 & 6.97 & 4 \\
Probability & $>0.50$ & $>0.80$ & $>0.10$ & -
\end{tabular}

TABle 8

The phenotypes of an $F_{2}$ progeny segregating for the character liguleless, and reaction to cereal cyst nematode

\begin{tabular}{|c|c|c|c|}
\hline \multicolumn{2}{|c|}{ Resistant $(\mathrm{Ha})$} & \multicolumn{2}{|c|}{ Susceptible $(h a)$} \\
\hline Ligules $(L i)$ & Liguleless $(l i)$ & Ligules $(L i)$ & Liguleless $(l i)$ \\
\hline 112 & 17 & 19 & 17 \\
\hline
\end{tabular}

Chi square values for segregation of the character liguleless $(\mathrm{Li} \mathrm{li})$, cereal cyst nematode reaction ( $\mathrm{Ha} \mathrm{ha}$ ) and linkage

$\begin{array}{lccc} & \text { d.f. } & \chi^{2} \text { value } & \text { Probability } \\ \text { Segregation of } \mathrm{Ha} \mathrm{ha} & 1 & 0.89 & >0.30 \\ \text { Segregation of } \mathrm{Lili} & 1 & 1.70 & >0.10 \\ \text { Linkage } & 1 & 16.60 & <0.001 \\ \text { Total } & 3 & 19.19 & <0.001\end{array}$

Partitioning of the chi square values (table 9) again indicated that linkage between the two loci was responsible for the disturbed $\mathrm{F}_{2}$ ratio.

Plotting the three point linkage values indicates that the $\mathrm{Ha}$ locus lies between $l i$ and $v$ on chromosome 2 .

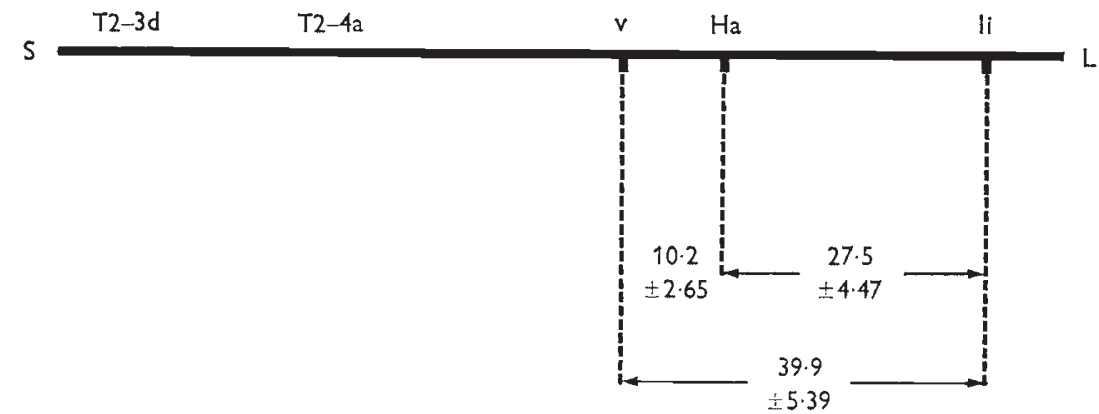




\section{Discussion}

Some difficulty was experienced in classifying certain plants as either resistant or susceptible, partly due to environmental variation and partly due to genetic variation in aggressiveness in the nematode. A wide range in the number of cysts produced on genetically homozygous susceptible genotypes was encountered even where plants were grown under uniform conditions, making it impossible to arrive at an overall numerical line of demarcation for resistance and susceptibility. Because of this, a statistical test was applied and by this method, members of the $\mathrm{F}_{2}$ populations were classified according to their highest level of probability of being included in a particular parental group. The lengthy procedure for determining the nematode reaction of plants precluded the screening of large $\mathrm{F}_{2}$ populations and, therefore, critical data are of necessity based on relatively low numbers of plants.

The results clearly show that there is a system of major genes for resistance to the cereal cyst nematode operating in the host. In the six genotypes used, resistance is controlled by at least three and possibly more genes at different loci. There is a single dominant gene $H a$ for resistance to races 1 and 2 in $\mathrm{Cb} 824$ (No. 191) which is located on chromosome 2, 27 units from $l i$ (liguleless) and 10 units from $v$ (six-row). There is also a dominant gene for resistance to race 1 only in $\mathrm{Cb} 917$ (Fero) and Cb 918 (Drost), and the data show that this gene in $\mathrm{Cb} 918$ is independent of, or only loosely linked to, $H a$. This result is confirmed by the work of Andersen and Andersen (1968). The monogenic resistance of $\mathrm{Cb} 1018$ (No. 14) to races 1 and 2 is also clearly at a different locus to the $\mathrm{Cb} 917$ and $\mathrm{Cb} 918$ genes. All the available evidence indicates that the genes for resistance in $\mathrm{Cb} 917$ and $\mathrm{Cb}$ 918 are at the same locus.

In the second series of tests which included the parents $\mathrm{Cb} 824$ and $\mathrm{Cb} 1018$, two susceptible plants were recovered in the $F_{2}$ population of the cross $\mathrm{Cb} 824 \times \mathrm{Cb} 1018$ (table 5). Statistical analysis showed that 95 per cent. of the $\mathrm{F}_{2}$ population of that cross could be expected to fall within the range $0-3$ cysts. The two plants in question bearing 19 and 22 cysts respectively lay far outside this range, but were within the 95 per cent. probability range for the susceptible check variety $\mathrm{Cb} 545$ ( 0 to 71 cysts), thus providing strong evidence that the resistance genes of $\mathrm{Cb} 824$ and $\mathrm{Cb} 1018$ are not at the same locus.

The gene for resistance in $\mathrm{Cb} 824$ is not the same as those in $\mathrm{Cb} 1022$ (C.I. 8334) and Cb 1023 (C.I. 3902), since unlike Cb 1022 and Cb 1023, the $\mathrm{Cb} 824$ gene is not effective against the Dutch race B (Kort et al., 1964). However, the resistance of $\mathrm{Cb} 1022$ and $\mathrm{Cb} 1023$ is no more effective than that of $\mathrm{Cb} 824$ against British races of cereal cyst nematode, since our tests have recently shown that all three genotypes are susceptible to the British race 3. The relationship of the genes for resistance in $\mathrm{Cb} 1022$ and $\mathrm{Cb} 1023$ with each other and with either $\mathrm{Cb} 824$ or $\mathrm{Cb} 1018$ is not fully established. With the data available it is evident that genes at the same locus or closely linked loci are involved.

The evidence for the location of $\mathrm{Ha}$ on chromosome 2 is clear. The genes for resistance in $\mathrm{Cb} \mathrm{1018,} \mathrm{Cb} 1022$ and $\mathrm{Cb} 1023$ are also located on this chromosome, since our results indicate that these genes are also closely linked to $\mathrm{Ha}$. If this is the case, the close location of loci controlling resistance to cereal cyst nematode on chromosome 2 would reflect the genetic situation 
with regard to mildew resistance where many factors for resistance to various physiologic races of the pathogen are found closely linked on chromosome 5 in barley (Moseman, 1963).

The gene $\mathrm{Ha}$ has now been introduced into adapted genotypes of spring barley which are effective against most of the British populations of cereal cyst nematode. However, additional genes for resistance will need to be found should race 3 or any as yet undetected race become prevalent as a result of growing such varieties on a large scale.

\section{Summary}

1. The genetic basis of resistance of six barley genotypes to two populations of the cereal cyst nematode which differed in their pathogenicity has been investigated; nematode resistance in these genotypes is characterised by the inability of the female to reach maturity in the root tissue.

2. Genetic analysis of $F_{2}$ populations showed that in each of four genotypes, resistance to a particular nematode population was controlled by a single dominant gene and in one of them $(\mathrm{Cb} 824=$ No. 191) resistance to both populations was controlled by the same gene.

3. Resistance was found to be controlled by genes at a minimum of three loci, with close linkage of two of these loci.

4. The dominant gene for resistance in $\mathrm{Cb}$ 824, designated $H a$, was found to be located on chromosome 2 , and has a recombination value of $10 \cdot 2 \pm 2 \cdot 65$ with the $v$ (6-row) locus and $27 \cdot 5 \pm 4 \cdot 47$ with the $l i$ (liguleless) locus.

Acknowledgments.-We wish to thank Mr D. A. East of the Statistics Department, University College of Wales, Aberystwyth, for advice on the statistical interpretation of some of the data.

\section{REFERENCES}

ANDERSEN, s. 1961. Resistens mod havreal Heterodera avenae. Meddr K. Vet.-og Landbohøjsk. No. 68 .

ANDERSEN, K., AND ANDERSEN, s. 1968. Inheritance of resistance to Heterodera avenae in barley. Nematologica, 14, 128-130.

COTтEN, J. 1963. Resistance in barley and oats to the cereal root eelworm Heterodera avenae Wollenweber. Nematologica, 9, 81-89.

Cotten, J. 1967. Cereal root eelworm pathotypes in England and Wales. Pl. Path., 16, 54-59.

HAXES, J. D., AND RANA, M. s. R. 1966. Genetic resistance to DDT in Hordeum. 1. Linkage studies in diploid barley. Heredity, Lond., 21, 581-593.

KORT, J., DANTUMA, G., AND VAN ESSEN, A. 1964. On biotypes of the cereal root eelworm (Heterodera avenae) and resistance in oats and barley. Neth. F. Pl. Path., 70, 9-17.

MOSEMAN, J. G. 1963. Function of the host and pathogen genetic systems in elucidating disease development. Barley Genetics 1. (Proc. First Internal. Barley Genetics Symp. Wageningen 1963), 215-221. 